 \\ International Journal of Social Sciences and Management
}

A Rapid Publishing Journal

ISSN 2091-2986

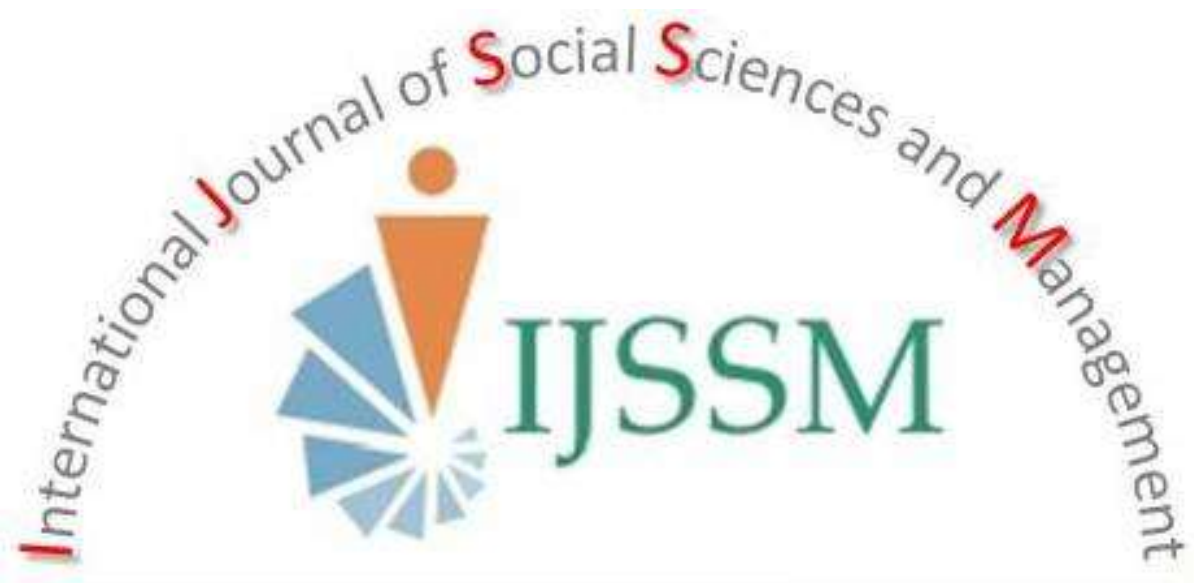

Available online at:

$\frac{h t t p: / / w w w . i j s s m . o r g}{\&}$

http://www.nepjol.info/index.php/IJSSM/index

SEM-Biotech

Publishing 


\title{
GLOBALIZATION AND THE AFRICAN ECONOMIC CRISIS: AN OVERVIEW Timothy Onimisi
}

Department of Political Science, Federal University Lokoja, Nigeria.

Email for correspondence: timothyonimisi@yahoo.com

\begin{abstract}
Globalization is a phenomenon that is fast sweeping through the world and of which Africa is not immune to, and it is very instrumental in molding the world from politics to economy, from religion to culture. In understanding the relationship that existing between the African economy and the wider world some economic indicators will be a useful tool in this analysis. The research focuses on how globalization has shaped the African economy, taking into cognizance the impact of the concept on Africa's key sectors like Poverty, Trade Relations, and Debt Burden. Haven identified the crisis associated with globalization as it relate to Africa's economy, the research recommend sustained and profitable engagement of Africa with the developed world and good governance is needed to strengthen the development process in African states if these recommendations are implemented the African economy will be strategically positioned in the complex theater of world economy.
\end{abstract}

Key Words: Globalization; Poverty; Trade Relations; Uneven Development; Debt Burden.

\section{Introduction}

Globalization is the current phenomenon shaping the market place today. With the wave of globalization hitherto independent markets and economy are been interlocked. Physical geographical boundaries are disappearing and geographical limitations for economic activities, capital movement of goods and services and technology are no longer relevant, rather liberalization, privatization and information technological changes have taken over.

Globalization requires some enabling environment for its full benefits to be realized. Democratization, economic growth, effective banking system, well organized and developed profit motivated private sector, vibrant small and medium scale enterprises, liberalization and so on will ensure maximum benefits from globalization (Oghojafor \& Ifekwem, 2008).

Globalization is a powerful real aspect of the new world system, and it represents one of the most influential forces in determining the future course of the planet. It has manifold dimensions: economic, political, security, environmental, health, social, cultural, and others. Globalization has had significant impacts on all economies of the world, with manifold effects. It affects their production of goods and services. It also affects the employment of labour and other inputs into the production process. In addition, it affects investment, both in physical capital and in human capital. It affects technology and results in the diffusion of technology from initiating nations to other nations. It also has major effects on efficiency, productivity and competitiveness (Intriligator, 2003).

Some scholars such as Dani (1999), David (1997), and Salimono (1999), opines that globalization opens opportunities. In the same vein, some view it as a process that is beneficial, a key to future world economic development that is also inevitable and irreversible (Sam, 2004).

Globalization in general offers extensive opportunities for truly world wide development but it is not progressing evenly, some countries are becoming integrated into the global economy more quickly than others, countries that have been able to integrate are seeing faster growth and reduced poverty (Sam, 2004).

Garry (1998) express fear about globalization, in the same vein, others regard it with hostility, even fear, believing that it increases inequality within and between nations, threaten employment and living standard and thwart social progress (Cited in Sam, 2004).

The greatest concern about globalization expressed by Awake (2002), is the ever increasing gap between the haves and the have not, he observed that while the global wealth has increased, it has become concentrated in the hands of the few privilege individuals and few countries.

This article clearly shows the place of Africa's economy in the global world and to broaden our understanding on the

Full text of this paper can be downloaded online at www.ijssm.org/ and http://nepjol.info/index.php/IJSSM/issue/archive 113 
impact globalization in Africa and how to deal with its impact.

\section{The Concept Globalization}

Globalization is a widespread concept with a considerable degree of ambiguity. This ambiguity does not mean that it remains unclear or ill defined. Globalization has been viewed from different perspectives and dimensions particularly in relation to different interests, subject areas and scope. Hence it has been difficult adopting a standard definition (Adesoji, 2006).However, like every other concepts in the social sciences that has suffered from definitional pluralism,globalization is no exception, definitions are product of a definer who to an immense extent is influenced by his environment.

According to Simpson and Weiner (1989), wasused in 1959 inTheEconomist to refer to quotas of car imports. This inaugural usage was followed in 1962 by a prescient article in The Spectator, which referred to globalization as "a staggering concept." Although no one at the time could have fathomed the global and local effects that it would engender, globalization grew slowly into a powerful term that has become a household word. Hotly contested and conveniently vague, globalization has taken on many meanings, from the warm, fuzzy connotations of the global village, through the rule of transnational corporations, to neo-colonialism (Sumner, 2008).

Globalization, according to Akindele (2002) refers to the process of the intensification of economic, political, social and cultural relations across international boundaries. It is principally aimed at the transcendental homogenization of political and socio-economic theory across the globe. It is equally aimed at "making global being present worldwide at the world stage or global arena".

It deals with the "increasing breakdown of trade barriers and the increasing integration of World market (Fafowora, 1998). In other words, as Ohuabunwa, (1999) once opined:

\section{"Globalization can be seen as an evolution which is systematically restructuring interactive phases among nations by breaking down barriers in the areas of culture, commerce, communication and several other fields of endeavor."}

This is evident from its push of free-market economics, liberal democracy, good governance, gender equality and environmental sustainability among other holistic values for the people of the member states.

Also, globalization has been viewed as the closer integration of the countries and peoples of the world which has been brought about by the enormous reduction of costs of transportation and communication and the breaking down of artificial barriers to the flows of goods, services, capital, knowledge and (to a lesser extent) people across borders. (Stiglitz, 2006).

An interdisciplinary term, globalization sits squarely at the interface between politics and the economy. (Ajekiigbe, 2004). To further buttress the argument of Ajekiigbe, Roseline (2011), posits that in Nigeria, the economy and society are gradually undergoing changes as a result of globalization which is also altering the industrial structure.

Its dominant form has come to be known by many names: corporate globalization, economic globalization, financial globalization, mature capitalism, neo-imperialism, neocolonialism, or globalization from above. One perspective attempts to define it as a process of reinforcement and extension of the international flux of commerce, capitals, technology and labour force. Another perspective refers to institutional changes, which are brought about in the society by the increase of these flows and the development of the transnational corporations, (Ajekiigbe, 2004). In this point of view, it stressed the weakening of the regulating function of the national states. In its stronger version, globalization implies the disappearance of the state in its economic dimensions while a subtler version considers globalization just as the loss of an important portion of the economic sovereignty. Yet another perspective refers to the growing homogenization of certain processes and behaviors like the introduction of global standards in the production of goods. However, the most extended idea in this perspective is the existence of a convergence in the demands of goods and services, a homogenization in the regulation of the capital goods and the technology(Ajekiigbe, 2004).

From a political economy perspective, corporate globalization involves "a set of structures and processes that build the private wealth of a very few people" (Sumner, 2005) Kwanashie (1998) shares this view and asserts specifically that globalization is a process of creating global market place in which all nations are increasingly forced to participate. The key elements of this process include the interconnection of sovereign nations through trade and capital flows; harmonization of the economic rules that govern relationship between the sovereign nations, and the creation of structures to support and facilitate dependence as well as the creation of a global marketplace. The process is accelerated by such openings, which the advancements in information technology have provided.

Contemporary globalization is highly information based. It combines progress in electronics, computing and telecommunication to come up with a highly dynamic process of storing, processing, transmitting and presentation of information. It gained momentum with the innovations and improvement in modern information, super highways has subsequently been viewed as emphasizing on the openness of trade, factor flows, ideas and information. Kolodko (2004) identified distinct phenomena, which he 
described as the fundamental features of modern globalization. First, is the increase in the volume of world trade to nearly twice as the volume of output. Second, is the obvious increase in the capital flows. The third reason is that globalization is also associated migrations. Having observed the far reaching cultural change and the post socialist systemic transformation, Kolodko argues that globalization is an irreversible process especially from the point of view of incredibly accelerated information flow and decreased communication and transformation cost.

Globalization is the acceleration and intensification of interaction and integration among the people, companies, and governments of different nations. This process has effects on human well-being (including health and personal safety), on the environment, on culture (including ideas, religion, and political systems), and on economic development and prosperity of societies across the world. This comprehensive and balanced definition takes into account the many causes and effects of the process, and, most importantly, leaves room for debate and discussion of the values that different people from all over the world bring to the table. Globalization has been described as another phase of imperialism. It has significantly reduced the barriers to interstate relations among nations. The core of globalization lies in freeing a country's economic frontiers to allow unrestricted international trade in goods and services, entry and exit of foreign capital and technology and giving the foreign investors a treatment similar to that given to domestic investors. (Narula, 2003).

A persistent state of unclarity thus surrounds the concept of globalization. Waters (1995), defines globalization as a "social power in which constrains of geography on social and cultural arrangements recede and in which people become increasingly aware that they are receding". Deviating further from more technology oriented views, it could also be argued that core aspect of globalization remains geographical. Globalization is constituted by transstate processes, indicating a specific scale of social activity transcending relations between nation-states (Taylor et al, 2002). It relates to the intensification of economic, political, social, and cultural relations across existing borders. (Holms and Sorensen, 1995)

From the foregoing, it could be seen that globalization conjures up a picture of a borderless world more often than not facilitated by the convergence of information and communication technologies.

Although it is a concept that means different things to different people across time and space, it essentially means the growing increase in interconnectedness and interdependences among the world's regions, nations, governments, business and institutions.
It is a process, which engenders free flow of ideas, people, goods, services and capital thereby fostering integration of economies and societies. Also, it should be clear that globalization in the economic sphere has developed over the last five centuries. It is therefore, not a recent experience although it must be granted as would be shown that it has acquired more vigour over the last two decades or so. Of critical importance, however, is the fact that globalization in the economic sphere has been a complex process developed and still develops by contradictions. It is therefore not enough to regard globalization simply as the process of bringing the different areas of the world together as an enlarged and integrated economic whole. The fundamental point must be emphasized, that globalization is driven and promoted by western capitalist and imperialist motives and values and has consequently produced two dialectically opposing classes of winners and losers among nations.

\section{The Impact and Consequences of Globalization in Africa}

\section{Poverty}

Globalization has not succeeded in reducing poverty, in the developing world with Africa worse off as hunger and starvation become common with drought and diseases ravaging the populace. Around 11 million people are in serious danger in need of food and drinking water in Kenya, Ethiopia, Eritrea, Somalia and Djibouti. Africa is the only developing region where poverty is on the increase (Thorberke, 1997). Sub - Saharan African countries therefore face challenges to raise growth and reduce poverty and to integrate them into the world economy. Economic growth is still not high to make a real dent in the pervasive poverty and enable these countries to catch up with other developing nations (Basu, 2000). Poverty has indeed become a major institution in Africa. Indeed, the continent's experience with poverty is alarming, $40 \%$ of its 600 million people live below the poverty line of the $1 \$$ per day (Aliegba, 2006). In many countries, 200 out of every 1000 children die before the age of 5, and more than 250 million lacks the access to safe water, 280 million have no access to health services (World Bank, 2000).

For Africa, globalization has become a threat to the poor rather than an opportunity for global action to eradicate (Obadina, 1998). For globalization is splintering many societies and doing little to eradicate poverty (UNRISED, 2000:2), the neo - liberal model has harmful consequences. But, they prefer to mask the damage rather than shift to more to humane and more productive forms of development (UNRISED, 2000:2). According to the United Nations Conference on Trade and Development (UNCTAD) report released on the $18^{\text {th }}$ of June 2002, "The current form of globalization is tightening rather than loosening the international poverty trap'. The report shows that extreme 
poverty in developing countries, which is defined using the one dollar - a - day international poverty line, has doubled over the pas 30 years, to 307 million people, and that more than 100 million people will be added by 2015 .

What about the wide spread hunger in Africa, can this be linked to globalization in anyway? Caroline Thomas, (Cited in Dayo, 2001) answered the question when she said "it is possible to explain the occurrence of hunger by reference to the process of globalization'. Adding that,

"Globalization can simultaneously
contribute to increased food production
and increased hunger: the south produces
over $40 \%$ of the world's food, but the
majority of hungry people live in the south.
Hunger in the south is not been reduced,
because self-sufficiency is been replaced
by cash crop production for agro -
business which is now a powerful force in
global politics."

\section{Uneven Development and Playing Field}

One of the most disappointing issues in globalization is its uneven process, with unequal distribution of its benefit and looses. This uneven nature of the present globalization process is manifest in the fast growing gap between the Worlds rich and poor, between the developed and developing world. This uneven playing field has succeeded in producing global asymmetries in terms of global distribution, extreme concentration of technology and wealth in advanced capitalist countries; macro economic vulnerability of developing countries; huge capital mobility and poor labour mobility; accessibility to global markets; and opportunities and the risks (Ocampo and Martin, 2003).

Equality is completely outside the era of globalization. Income and wealth concentration and social instance are uneven, the income gap between the fifth world's people living in the richest countries and the fifth in the poorest countries was $74-1$ in 1997 up to $60-1$ in 1990 and $30-$ 1 in 1960 (Aliegba, 2006). These fifth in the richest countries have $86 \%$ of the world GDP, $82 \%$ of the world export markets, $68 \%$ of the foreign direct investment, and $74 \%$ of world telephone lines (Aliegba, 2006). The world 200 richest people more than double their net worth in the four years to 1998 , to more than $\$ 1$ trillion. The top three billionaires are more the combine GNP of all least developed (UNDP, 2003). This contrast with the situation of where about 1.2 billion people one fifth of the worlds population are trapped in absolute poverty living below $\$ 1$ per day. Half of this world population lives on less than $\$ 2$ per day.

Even the condition upon which globalization operates is not even fair to the developing countries nor are the gain too. The Norwegian Prime minister, Kiell Magne Bondevik, draws an analogy between the game and globalization when he observed that:
"The soccer players are fortunate to play on the level field, by the same rules, with referees to ensure even handed applications. The development field is far less level. These rules are clear and more unevenly applied. Some refuse to play fields not their liking. There are no generally recognized referees. This is the challenge that the poor face".

This unfair trade rules frustrate trade between Africa and south. For instance trade between Africa and other Asian countries have to go through other third parties in Europe (Kearney, 2006:9). The president of South Africa, Thembo Mbeki did observe that:

\begin{abstract}
"Every day the process of globalization emphasizes the gross imbalance in the global distribution of power, making it imperative that we use our collective strength to achieve the restructuring and demonstration of the United Nations and other multi - lateral organizations"
\end{abstract}

(Kearney, 2006).

\section{Trade Relations}

Globalization has facilitated the expansion of trade volume but in a disproportional way dominated by countries of the north who account for $70 \%$ of total trade. The share of trade by developing countries is only one fifth of the world trade, while this share is seen to be increasing, six countries of East Asia Taiwan, Singapore, Hongkong, South Korea, Malaysia and Thailand are responsible for this increase (Aliegba, 2006). Their share of world trade increased from $2.6 \%$ in 1953 to $10 \%$ in 1999 . In contrast Africa and Latin America saw their share of world trade fall in this period (Oatley, 2003). Africa's share of world trade and global production is quite low and has even continued to decline in the last two decades. Africa's share of international trade which was about $5 \%$ in the 1980 s, came down to $2 \%$ in 2000.its trade terms has worsened too (UNCTAD,2001).

Opponents of the process of globalization indicated that the impact of globalization on developing and developed countries differed. Although a big numbers of countries developed serious financial problems, which led to an increase in the gap between developed and developing nations. Between 1980 and 1990 more than $90 \%$ of all financial transactions of the world were executed in 25 of 121 countries worldwide (Hak - Min, 1999). The low income countries share in the globalized capital flows were less than $1 \%$ of the total worldwide transactions. These developments are seen as transnational stage in the development of capitalism.

According to Ohmae (1985), the global economy is dominated by three regional blocks, namely America, Europe and Japanese dominated Asian bloc. The three regional blocks were responsible for $43 \%$ of all global 
capital transactions and for $56 \%$ of all portfolio transactions between 1980 and 1990 .

Despite the process of globalization, $72 \%$ of Germany's exports and $78 \%$ imports were still to western industrialized countries between 1980 and 1990 (Hak - Min, 1994). Despite the initiative to improve the level of trade with countries in Africa, only $2.6 \%$ of goods and services were imported from the rest of Africa. The conclusion can be made that the globalization process has not increased the participation of Africa in trade relations.

\section{Debt Burdens and Foreign Direct Investments}

Africa has a very huge debt burden as a result of unequal trade and economic terms. Africa's debt burden today is twice that of any region in the world. It has $11 \%$ of the developing world debt but with only $5 \%$ on its income. Thirty five of the world 40 most indebted countries are in sub - Saharan Africa. The 48 nation of sub - Saharan Africa owe $\$ 227$ billion mostly to government and international financial institutions of the IMF and the World Bank (NEPAD, 2005). African countries spend $\$ 3.5$ billion every year on debt payment. These direct resources form basis human needs of health and education. They also undermine Africa's government effort to promote sustainable development. The UN report has revealed that between 1970 and 2002 African countries received \$540 billion in loans paid back close to $\$ 550$ billion principal and interest and still had \$295 billion in debt at the end of 2002 (Cited in NEPAD, 2005).

Globalization has in no way helped to alter the position of Africa in real direct investment inflow. For instance average foreign direct investment (DFI) flows to Africa doubled during the 1980s to $\$ 2.2$ billion compared in 1990s and to $\$ 13.8$ billion between 2000 and 2003 (Aliegba, 2006). Yet, what Africa receives amount to only two to three percent of global FDI flows down a peak of $28 \%$ in the 1970s. FDI is not accompanied with forward and backward linkage nor is the profit invested in the domestic economy (Okoth, 2005).

The implication for this is massive transfer and repatriation of resource or investable capital out of Africa competing for foreign direct investment are the industrialized economies that draw more than $80 \%$ FDI, Asia with more than $10 \%$ and Latin America with around 5\% (Aliegba, 2006), Africa accounts for less than $2 \%$ of FDI inflows. It is unlikely that Africa is going to experience a sudden boost of FDI under this situation. Suddenly, it was insufficient to begin addressing its development backlog. Africa is not priority for the majority of northern countries and even less after the cold war. The Middle East, Asia especially China and parts of Latin America are priority concerns for U.S and European foreign policy (Aliegba, 2006). Also, FDI flows to Africa (including South Africa) declined form $\$ 10.5$ billion in 1999 to $\$ 9.1$ billion in 2000. For sub - Saharan African, the same FDI decreased from $\$ 8$ billion in 1999 to
$\$ 6.5$ billion in 2000. Africans share for global FDI was less than $1 \%$ in 2000 (UNCTAD, 2001).

\section{Conclusion and Recommendations}

Given the reality of the African situation as presented, it is obvious that globalization will continue to create a situation of continued subordination and subjugation of the South by the North - Africa is indeed worse up as Asia and Latin America have proved their capability to stand up to this challenge, hence the hope their seeming liberation as their economies and democracies are definitely doing better. The emergence of the newly industrialized countries in Asia and Latin America also attest to this. Africa obviously seems to be truly the doomed region. To change this situation for the better it must therefore go to the drawing tables. The following are some recommendations.

1. The need for sustained and profitable engagement by Africa with developed world so as to try and reverse for good, the beggarly and highly embarrassing image of the continent. Thus the new partnership for Africa Development (NEPAD) initiatives is a good approach which mostly seeks to halt the growing and deepening poverty of Africa by altering the basis of the relationship between the North and South. This approach seeks a partnership based on shared responsibility and mutual interest through the instrumentality of political democracy and economic development of the continent. This is to help enthrone market oriented economies capable of holding their ground in the global village. More over it is capable of making Africa lay a foundation for a strong facilitated and economic order to eliminate poverty on the continent. This must however be done with commitment from African leaders to truly change the situation and not be dependent on foreign support.

2. The economic blue prints of the Lagos plan of Action for economic development of Africa. (1980-2000) and the final Act of Lagos of 1980 must be put in place. The plan provides a basis for creation of integrated and dynamic national sub regional and regional markets. The five provision of the plan include:

- The deliberate promotion of an increasing measurement of national self-reliance.

- The acceleration of internally located and relatively autonomous process of growth and dissatisfaction and achievement of self-sustained development process.

- The democratization of the development process.

- The progressive eradication of mass poverty and unemployment a fair and just distribution of income and benefits of development among the populace; and

- The acceleration of the process of regional economic integration 
through cooperation (cited in Aliegba, 2006)

3. It has been observed that the Lagos plan of action sought to adopt a new development strategy of inward looking pattern. It emphasized among others the development of domestic market in Africa rather reliance on external markets, the control of natural resources by states, the role and importance factor is put in food production, the development of human capital and provision of social infrastructure for the African people.

4. Good governance for African is what is needed to strengthen the development process in African states in order to make state to be relevant to its people. This if taken seriously will redirect the African states toward the expected focus. However only good leadership will develop such state. There is therefore the need for civil society pressure to democratize only African states to achieve this.

5. There is need to address corruption in African states. For corruption deprives the states of investible funds. It is also lower standard and equality policies and physical project and standards in physical projects and standards physical policies. The institutions of governance are greatly weakened by massive corruption in African states as government tend to loose legitimacy and also support for development assistance in donor development countries(Aliegba, 2006). Hence there is need to strengthen the institutions in Africa and they have to be proactive

\section{References}

Adesoji AA (2006) Globalization of the Media and the Challenges of Democratization Nigeria. Nebula 3(4):38-50.

Ajekiigbe J (2004) Effects of Globalization and Universal Banking in Nigeria. The Guardian, $27 \& 31$.

Akindele ST (2002) Globalization. Its Implication and Consequences for Africa, Political Science Dept., ObafemiAwolowo University, African Post-Colonial Literature, in the Post-colonial Web, http;/globalization./caap;org/contend/vq.1/akindele-etal. Retrieved 12/04/2012

Aliegba TE (2006) Globalization and The South: Towards a new African political and Economic Focus. A paper presented at the International Conference on: Africa, Globalization and Justice, Catholic University of Eastern Africa, Nairobi: 1 - 19.

Basu A (2000) Promoting Growth in Sub - Saharan Africa: Learning what Works. Economic Issues, No. 23, Washington DC: IMF

Campo J and Martin J (2003) Globalization and Development: A Latin American And Caribbean Perspective .Stanford: Stanford University Press.

Dani R (1999) The New Global Economic and the Developing countries. Making Openness Work Baltimore. John Hopkin University Press
David V (1999) Barrier or Benefits? Regulation Transatlantic Trade. Washington D.C: Brookling Institute Press.

Dayo K (2001) Is Globalization Exacerbating or Alleviating Poverty and Underdevelopment in Africa? African Journal of International Affairs and Development, 6(2): 1 -10 .

Fafowora OO (1998) Management in Nigeria. Journal of Nigerian Institute of Management, 34(2-4): 5-9.

Gary B (1998) Globalization Confronting Fear About Open Trade. Washington, D.C: Brookings Institute Press.

Hak-Min K (1999) Globalization of International Financial Market: Causes and Consequences, Hants: Ash gate Publishing Limited.

Holms H and Sorensen G (1995) Introduction: What Has Changed? In Whose World Order? Uneven Globalization and the End of the Cold War, Eds. H-H Holm and GSorensen. Boulder, CO Westview, pp. 1-17

Intriligator MD (2003) Globalization of the World Economy: Potential Benefits and Costs and A Net Assessment. Los Angeles: University of California

Kearney M (2006) Africa: Globalization Hurting Continent, Jarkatta Newsletter, April, $25^{\text {th }}$.

Kolodko GW (2004) Globalisation and Catching up of in Emerging Market Economies.Text of Public Lecture delivered at the Nigeria Institute of International Affairs (NIIA) Lagos, Nigeria Friday, July 16

Kwanashie M (1998) Central Bank Economic and Financial Review, Vol 36, No. 4.

Mulume G (2003) Hopes Seen in the Ashes of Cancun, Africa Recovery, 17(3)

Narula S (2003) Globalisation: India's Experience for the African Continent. DPMF Occasional Paper, No. 7, Development Policy Management Forum, Addis Ababa

New Partnership for African Development (NEPAD) (2005) Concept paper for the African Parliamentarians on the New Partnership for African Development, Abuja, Nigeria.

Oatley T (2003) International Political Economy: Interest and Institutions in the Global Economy, New York: Parson and London.

Obadina T (1998) Globalization, Human Rights and Development Friday, October $16^{\text {th }}$.

Ohmae K (1985) Triad Power: The Coming Shape of Global competition, New York: Free Press.

Ohuabunwa Mazi SI (1999) The Challenges of Globalisation to the Nigerian Industrial Sector Nigerian Tribune, December 14, pp. 20-21.

Roseline O (2011) Globalization and Human Resource Development in Nigeria, American Journal of Social and Management Sciences, 2(2): 217-219.

Full text of this paper can be downloaded online at www.ijssm.org/ and http://nepjol.info/index.php/IJSSM/issue/archive 118 
Salimono A (1999) Globalization and Challenges. A Paper Presented at the International Summit on Globalization as Problem of Development in Harana Cuba.

Sam EO (2004) Globalization and the Political Future of Nigeria. The Guardian, $27 \& 31$.

Simpson J and Weiner E (1989) Oxford English Dictionary (2nd ed.). Oxford, UK: Clarendon.

Stiglitz J (2006) The Information Age Globalization. Wikibooks. The Open contact textbook Collection.

Sumner J (2008) Governance, Globalization, and Political Economy: Perspectives from Canadian Adult Education, Adult Education Quarterly, 59(1): 22-41.
Taylor P, Watts M and Johnston R (2002) Geography/Globalization. In: Johnston RJ, Taylor PJ and Watts MJ (eds) Geographies of Global Change, $2^{\text {nd }}$ edition. Oxford:Blackwell, 1-18

Thorbeoke T (1997) Wither Africa? African Notes, April, $14^{\text {th }}$.

United Nations Centre for Trade and Development UNCTAD (1999) Trade and Development Report, New York and Geneva: United Nations

United Nations Development Programme (1999) Human Development Report, New York: United Nations

Waters M (1995) Globalization. London, Routhdge 